Copyright (C) 2021 by Cherkas Global University

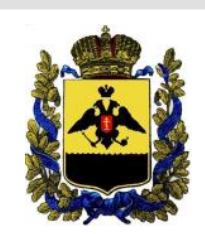

Published in the USA

Bylye Gody

Has been issued since 2006.

E-ISSN: $2310-0028$

2021. 16(4): 1737-1750

DOI: $10.13187 /$ bg.2021.4.1737

Journal homepage:

https://bg.cherkasgu.press

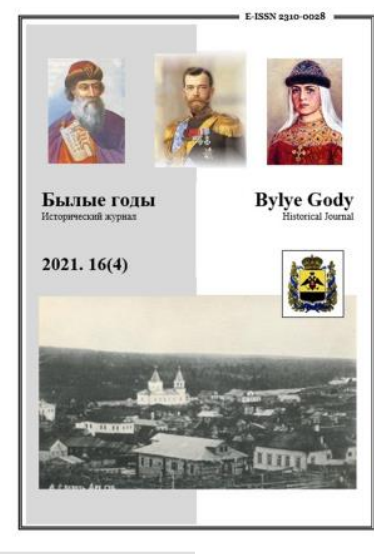

\title{
Civilization Mission of the Russian Empire in Central Asia in the 19th century (Based on Materials from the State Archive of the Orenburg Region)
}

\author{
Valerii L. Muzykant a , *, Galina N. Trofimova a, Valerii D. Takazov a, Almas Kalimoldaev b \\ a Peoples Friendship University of Russia (RUDN University), Moscow, Russian Federation \\ b Al-Farabi Kazakh National University, Almaty, Kazakhstan
}

\begin{abstract}
The work examines the civilizational mission of the Russian Empire in Central Asia in the XIX century on the basis of archival sources. The attention is paid to the main types of crimes, such as kidnapping, murder, robbery of merchant caravans, sea robbery, barymta, as well as the system of punishment for these crimes.

The inventory No. 10 (1st, 2nd, 3rd and 4th parts) of the State Archive of the Orenburg Region (Orenburg, Russian Federation) of the Fund No. 6 was used as materials, which presents the cases of the border department of the office of the Orenburg Governor-General.

In conclusion, the authors state that in the first half of the XIX century, the Russian Empire in Central Asia faced a whole range of serious criminal acts, namely kidnapping and slave trade, murders, robbery of trade caravans and fishing vessels, nomad raids and barymta (abduction of horses and cattle). Only in the state archive of the Orenburg region about 2 thousand archival files were devoted to these issues. The illegal acts involved, especially at the initial stage, not only the nomads of the Kyrgyz steppe, but also the Kyrgyz who are part of Russia (the Inner Horde).

Since 1820 , Russia has been working tirelessly to spread literacy in the steppe, provide medical and humanitarian assistance, attract local people to service (first as postmen, then as guards for sultans and caravans, and then until entering the civil service after graduating from Russian educational institutions). Thanks to this, the steppe began to change, this process was long and complicated, but in general, by the 1870 , the number of criminal offenses in the region was minimized, and Central Asia was able to adopt many initiatives proposed by the Russian administration. Persia.

Keywords: Central Asia, Khiva, Bukhara, the Inner Horde, nomads, Kyrgyz steppe, Russian Empire,

\section{1. Введение}

К началу XIX века Российская империя вышла на границы с Центральной Азией (значительная часть этой территории сегодня в составе Республики Казахстан). В 1801 г. из части территории Киргизской степи было создано и включено в состав Российской империи Бекеевское ханство, которое также было известно как Внутренняя орда. С этого времени Российская империя вступила в цивилизационный диалог, пытаясь найти точки соприкосновения как с вступившим в состав России населением, так и с кочевниками и центральноазиатскими ханствами (Хивинским и Бухарским). Кочевой образ жизни местного населения, укоренившиеся традиции набеговых практик - все это привело к тому, что практически сразу русской администрацией начало фиксироваться большое количество случаев похищений и продажи русских людей, грабежей и массовый угон лошадей (барымта). В данной работе
\end{abstract}

\footnotetext{
${ }^{*}$ Corresponding author

E-mail addresses: muzykant_vl@pfur.ru (V.L. Muzykant)
} 
делается попытка рассмотреть спектр действий российской администрации, направленный на прекращение асоциального поведения населения Киргизской степи.

\section{2. Материалы и методы}

В качестве материалов была использована опись № 10 (1-4 части) фонда № 6 Государственного архива Оренбургской области (Оренбург, Российская Федерация), в которой представлены дела пограничного отделения канцелярии оренбургского генерал-губернатора.

В 1-й части 10-й описи - 2175 архивных дел, которые охватывают период с 28 апреля 1795 г. по 2 января 1819 г.

Во 2-ю часть 10-й описи внесено 2425 архивных дел. Они охватывают период с 3 января 1819 г., хотя среди документов иногда попадаются и более ранние.

В 3-ю опись включены 2356 архивных дел. Документы 3-й описи охватывают период с 4 января 1835 г., хотя и здесь есть более ранние исключения.

В 4-й описи 2369 архивных дел. Документы этой описи охватывают период с мая 1850 г.

Всего в коллекции 10-й описи насчитывается 9335 архивных дел.

В исследовании в качестве одного из главных методов использована теория модернизации традиционного общества, с помощью которой можно рассматривать процесс трансформации населения Киргизской степи под влиянием русской цивилизации. В работе был также применен метод объективности, который позволил рассмотреть все случаи цивилизационного диалога, в том числе и непопулярные. Важное значение было также уделено хронологическому методу, благодаря которому мы рассмотрели события в их хронологической последовательности.

\section{3. Обсуждение}

Вопросы взаимоотношений Российской империи с центральноазиатскими ханствами периода XVIII-XIX вв. в последнее время активно изучаются. Исследователи обращают внимание на социально-экономические, политические и военные аспекты диалога между Хивинским и Бухарским ханствами, с одной стороны, и Российской империей - с другой.

Так, например, Р.Ю. Почекаев рассматривал особенности правового регулирования статуса российских торговцев в Центральной Азии (Почекаев, 2015), позднее этот же автор анализировал использование российских войск в среднеазиатских протекторатах (Почекаев, 2020). В то же время Г.Б. Избассарова исследовала сложный процесс интеграции азиатов в российское пространство на примере султана Кайпгали Ишимова (Izbassarova, 2020). S.P. Poullada сделал попытку рассмотреть каспийский фронтир до Большой игры (Poullada, 2018).

В последнее время исследователями делались попытки рассмотреть и такую сравнительно слабоизученную проблему, как рабство в Центральной Азии. Так, например, группа авторов И.А. Ермачков и другие - привлекла в качестве источника дело о возвращении 80 русских пленников из Хивы (Ermachkov, 2021). В то же время другая группа авторов - С.В. Зинковский и другие - сделала попытку рассмотреть азиатское рабство в сравнении его с рабством на Кавказе (Zinkovskii et al., 2021).

Обращались авторы и к сугубо военным аспектам покорения Азии. Так, М.Г. Тарасов рассмотрел поход казаков на Хиву в 1839-1840 гг. (Tarasov, 2021). И.А. Зварцев уделил внимание такому аспекту, как окончательное завоевание Туркестана Российской империей (Зварцев, 2021). Близкая по тематике работа подготовлена Е.В. Годововой - «Присоединение Средней Азии к России: особенности военно-походной повседневности казаков в Хивинском походе 1873 г.» (Годовова, 2019)

С.С. Вдовин и Ж.З. Сыздыкова рассматривали этнический состав и территориальное устройство Хивинского ханства в XVIII-XIX вв. (Вдовин, Сыздыкова, 2021). Р.Т. Ганиев изучал хивинскую проблему Российской империи (Ганиев, 2013). К кризисным явлениям в развитии среднеазиатского направления внешней торговли России на оренбургском направлении в первой четверти XIX века обратился С.В. Любичанковский (Любичанковский, 2017). Вопросами водворения русской государственности в Центральной Азии занималась Ш. Мухамедина (Мухамедина, 2016).

\section{4. Результаты}

Весьма примечательно, что уже первое архивное дело от 28 апреля 1795 г. было посвящено переписке о попытках налаживания мирных взаимоотношений с Бухарой и киргиз-кайсацкими ордами, а также борьбе с набегами кочевников на купеческие караваны (ГАОО. Ф. 6. Оп. 10. Д. 1).

Вызовы, с которыми пришлось столкнуться Российской империи, многочисленны: это и похищения людей, работорговля, грабежи караванов и судов, убийства и наиболее распространенное - барымта (к ней относилось похищение лошадей и крупного рогатого скота). Борьбу с этими укоренившимися в народе преступлениями и пришлось вести администрации Российской империи в Центральной Азии на протяжении почти всего XIX века. 
Bylye Gody. 2021. 16(4)

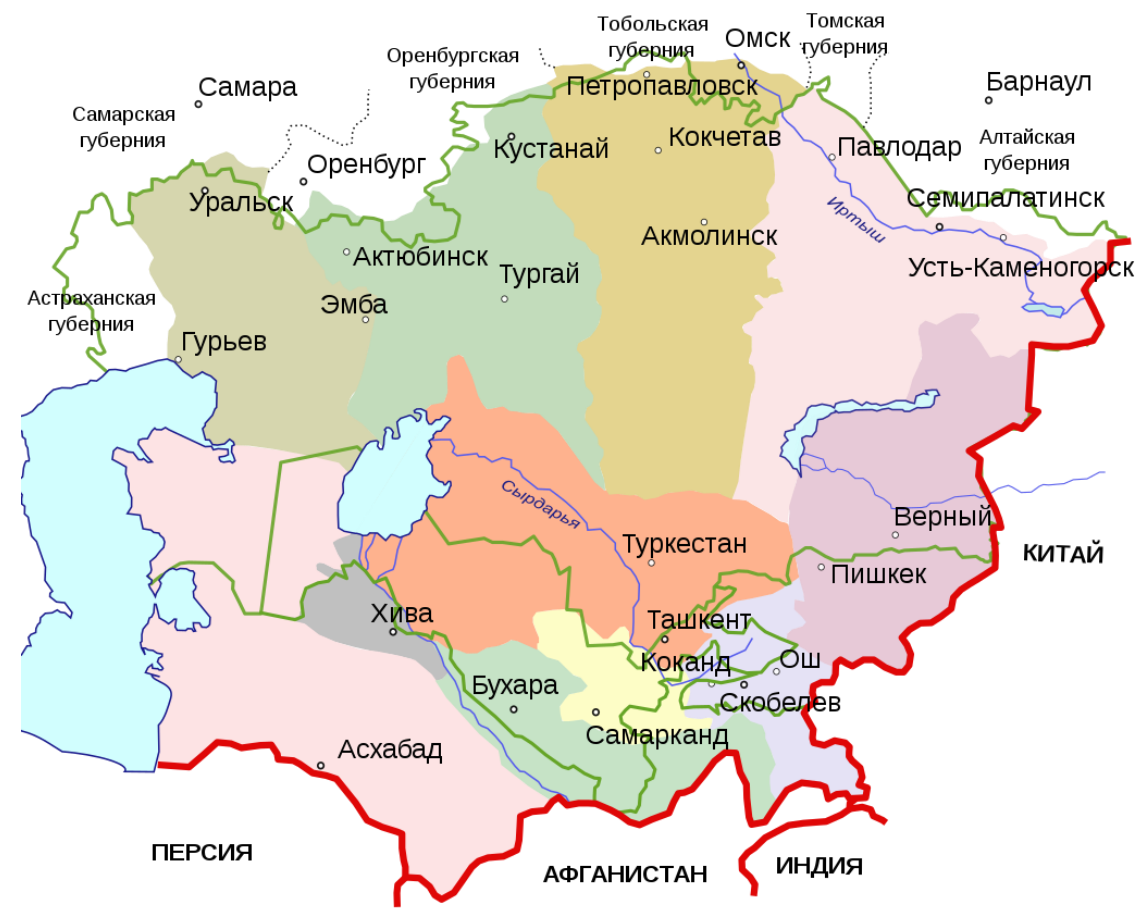

Рис. 1. Карта центральноазиатских территорий в XIX веке

Для представления масштабов преступности в регионе мы свели данные в Таблицу 1. Необходимо пояснить, что здесь речь идет только о преступлениях, зафиксированных в переписке, отложившейся только в Оренбурге (в канцелярии оренбургского генерал-губернатора). Но даже эта неполная картина дает представление о масштабах преступности в регионе.

Таблица 1. Количество дел о преступлениях за 1795-1880 гг.

\begin{tabular}{|l|l|l|l|l|l|}
\hline \multirow{2}{*}{ Годы } & \multicolumn{3}{|c|}{ Плен, рабство } & \multicolumn{2}{|c|}{ Грабежи } \\
\cline { 2 - 5 } & Захвачено & Освобождены из плена & Караваны & Прочие & \\
\hline 1795 & Д.н. & Д.н. & Д.н. & 1 & Д.н. \\
\hline 1796 & Д.н. & Д.н. & Д.н. & Д.н. & Д.н. \\
\hline 1797 & Д.н. & Д.н. & Д.н. & Д.н. & Д.н. \\
\hline 1798 & Д.н. & Д.н. & Д.н. & Д.н. & Д.н. \\
\hline 1799 & Д.н. & Д.н. & Д.н. & Д.н. & Д.н. \\
\hline 1800 & Д.н. & Д.н. & Д.н. & 1 & Д.н. \\
\hline 1801 & Д.н. & Д.н. & Д.н. & 1 & Д.н. \\
\hline 1802 & Д.н. & Д.н. & Д.н. & Д.н. & Д.н. \\
\hline 1803 & 2 & - & 1 & 1 & 2 \\
\hline 1804 & 1 & 5 & - & 4 & 22 \\
\hline 1805 & 4 & 3 & - & 9 & 15 \\
\hline 1806 & 6 & - & - & 8 & 8 \\
\hline 1807 & 10 & - & - & 6 & 19 \\
\hline 1808 & 7 & 4 & - & 3 & 22 \\
\hline 1809 & 8 & 7 & - & 8 & 31 \\
\hline 1810 & 1 & 3 & - & 7 & 13 \\
\hline 1811 & 4 & - & - & 7 & 12 \\
\hline 1812 & 5 & 9 & - & 5 & 15 \\
\hline 1813 & 2 & 5 & - & 15 & 20 \\
\hline 1814 & 6 & 4 & - & 9 & 40 \\
\hline 1815 & 6 & 2 & 2 & 3 & 22 \\
\hline 1816 & 3 & 2 & - & 4 & 26 \\
\hline 1817 & 5 & 4 & 2 & 10 & 23 \\
\hline 1818 & 6 & 7 & 1 & 10 & 24 \\
\hline 1819 & 1 & 3 & 2 & 15 & 23 \\
\hline
\end{tabular}

${ }_{1}^{1}$ Данных нет. 
Bylye Gody. 2021. 16(4)

\begin{tabular}{|c|c|c|c|c|c|}
\hline 1820 & 4 & 9 & 1 & 8 & 29 \\
\hline 1821 & 3 & - & 1 & 9 & 47 \\
\hline 1822 & 15 & 7 & 1 & 16 & 68 \\
\hline 1823 & 20 & 9 & - & 20 & 44 \\
\hline 1824 & 8 & 7 & - & 9 & 40 \\
\hline 1825 & 7 & 2 & - & 1 & 4 \\
\hline 1826 & 8 & 2 & - & 4 & 3 \\
\hline 1827 & 3 & 1 & - & 3 & 1 \\
\hline 1828 & 2 & 3 & - & 6 & 6 \\
\hline 1829 & 2 & 6 & 2 & 5 & 5 \\
\hline 1830 & 4 & 5 & 1 & 4 & 19 \\
\hline 1831 & 2 & 8 & - & 9 & 10 \\
\hline 1832 & 4 & 6 & - & 10 & 20 \\
\hline 1833 & 5 & 6 & 1 & 10 & 11 \\
\hline 1834 & 1 & 4 & - & 10 & 15 \\
\hline 1835 & 1 & 11 & - & 7 & 23 \\
\hline 1836 & 3 & 6 & - & 12 & 14 \\
\hline 1837 & - & 3 & 1 & 13 & 11 \\
\hline 1838 & 2 & 6 & - & 14 & 13 \\
\hline 1839 & - & 5 & 1 & 8 & 6 \\
\hline 1840 & 2 & 1 & 1 & 8 & 8 \\
\hline 1841 & - & 5 & - & 7 & 8 \\
\hline 1842 & 2 & 3 & - & 10 & 6 \\
\hline 1843 & 1 & 1 & 1 & 10 & 6 \\
\hline 1844 & 1 & - & - & 4 & 5 \\
\hline 1845 & 1 & 2 & 2 & 7 & 7 \\
\hline 1846 & - & 2 & 1 & 11 & 10 \\
\hline 1847 & 2 & 3 & 3 & 18 & 9 \\
\hline 1848 & 2 & 1 & 1 & 7 & 17 \\
\hline 1849 & 2 & 3 & 1 & 8 & 24 \\
\hline 1850 & - & 5 & - & 10 & 6 \\
\hline 1851 & - & 2 & - & 14 & 11 \\
\hline 1852 & - & 1 & - & 14 & 7 \\
\hline 1853 & 1 & 8 & 2 & 6 & 6 \\
\hline 1854 & - & 1 & - & 6 & 12 \\
\hline 1855 & - & 4 & - & 10 & 6 \\
\hline 1856 & - & - & 1 & 5 & 3 \\
\hline 1857 & - & 2 & 2 & 9 & 6 \\
\hline 1858 & - & 2 & - & 6 & - \\
\hline 1859 & - & 1 & - & 4 & 2 \\
\hline 1860 & - & 1 & 1 & - & 1 \\
\hline 1861 & - & - & - & 1 & - \\
\hline 1862 & - & 2 & 1 & 1 & - \\
\hline 1863 & - & 1 & - & 2 & 2 \\
\hline 1864 & - & 1 & - & 1 & 5 \\
\hline 1865 & - & - & - & 5 & 1 \\
\hline 1866 & - & 1 & - & 4 & 1 \\
\hline 1867 & - & - & 1 & 2 & 5 \\
\hline 1868 & - & - & - & 1 & 2 \\
\hline 1869 & 1 & 1 & - & 2 & - \\
\hline 1870 & - & - & 1 & - & - \\
\hline 1871 & - & 1 & 1 & 1 & - \\
\hline 1872 & - & - & - & 1 & 4 \\
\hline 1873 & - & 1 & - & - & - \\
\hline 1874 & - & - & - & 1 & - \\
\hline 1875 & - & - & - & - & 2 \\
\hline 1876 & - & - & - & - & - \\
\hline 1877 & - & - & - & - & 1 \\
\hline 1878 & - & - & - & - & 1 \\
\hline 1879 & - & - & - & - & 1 \\
\hline
\end{tabular}




\begin{tabular}{|l|l|l|l|l|l|}
\hline 1880 & - & - & - & 2 & - \\
\hline Итого & 186 & 220 & 37 & 503 & 911 \\
\hline
\end{tabular}

Таблица 1 разделена на три части преступлений: первая - это захват людей в плен, здесь мы выделили также количество дел об освобождении из плена; вторая - грабежи, включает в себя набеги, ограбления, убийства. Отдельно мы выделили информацию об ограблениях торговых караванов; третья и самая массовая часть дел - это барымта, а именно кража лошадей и крупного рогатого скота. Важно отметить, что примерно в $10 \%$ случаев в одном деле содержались и ограбления, и барымта, а иногда и похищение людей, в таких случаях дело указывалось по тяжести преступления - либо в похищении, либо в грабежах. Об объемах уголовных дел по данным преступлениям дает представление часть «Итого» Таблицы 1.

Документов в Государственном архиве Оренбургской губернии за период с 1795 по 1802 гг. практически нет, ввиду этого в Таблице 1 в указанные годы во многих графах мы поставили значение «данных нет».

В начале XIX века Российская империя имела протяженную государственную границу с центральноазиатскими соседями, которая начиналась от Каспийского моря и до границы с Китаем. На протяжении первой половины XIX века большую проблему для русской администрации представляли практически не управляемые племена кочевников, которых в то время называли киргизами или туркменами. На прекращение бесчинств банд рабозахватчиков на русской территории и будет направлена деятельность Российской империи.

Нужно понимать, что похищение (людей и лошадей), а также работорговля существовали в значительных размерах в Центральной Азии. Спрос на пленников был очень высок, так как трудом рабов (персов и частично русских) обрабатывались земледельческие угодья в Хивинском и Бухарском ханствах. Кочевники поставляли этих рабов, а взамен получали необходимые им зерновые товары. По мере усиления России на границе с Центральной Азией встал вопрос и о прекращении набегов на русскую территорию. В начале XIX века Центрально-Азиатский регион представлял собой подобие слоеного пирога, где между границей России, с одной стороны, и Хивой и Бухарой - с другой, были вассальное казахское ханство Внутренняя орда (другое ее название Букеевская орда) в составе Российской империи и децентрализованные кочевники. Особенно на начальном этапе своей цивилизационной миссии русским приходилось изменять мировоззрение как кочевникам, так и представителям Внутренней орды.

Для лучшей визуализации количество дел по конкретным видам преступлений мы представили на Рисунках 2-5.

\section{Убийства, похищения, работорговля}

Согласно данным Рисунка 2, видно, что первые случаи захвата пленников кочевниками, отраженные в документах Государственного архива Оренбургской области, относятся к 1803 г. Пик такой активности кочевников приходится на 1823 г., после чего начинает снижаться, а с 1850-х гг. дела о похищении людей практически прекращаются, исключение составляет только одно дело в 1869 г.

Рассмотрим некоторые случаи этих захватов, а также меры наказания как за захваты, так и за работорговлю.

В 1817 г., по всей вероятности при попытке захвата в плен, на рыбных промыслах были убиты русские крестьяне (ГАОО. Ф. 6. Оп. 10. Д. 1786). В том же 1817 г. за работорговлю преступников наказывали кнутом (ГАОО. Ф. 6. Оп. 10. Д. 1897). В 1818 г. был захвачен в плен и убит рыбопромышленник (ГАОО. Ф. 6. Оп. 10. Д. 6282а). В 1822 г. за незаконный переход русской границы и похищение двух русских крестьян преступников наказывали кнутом и ссылкой на каторгу (ГАОО. Ф. 6. ОП. 10. Д. 2901).

В 1823 г. в Каспийском море были захвачены в плен русские рыбаки (ГАОО. Ф. 6. Оп. 10. Д. 3010). Чтобы прекратить налеты и захват рыбаков, в Степь в сентябре 1823 г. была направлена русская военная экспедиция (ГАОО. Ф. 6. Оп. 10. Д. 3040а).

В 1824 и 1825 гг. произошло 4 захвата русских людей на рыбном промысле (ГАОО. Ф. 6. ОП. 10. Д. 3199; ГАОО. Ф. 6. Оп. 10. Д. 3209; ГАОО. Ф. 6. Оп. 10. Д. 3233; ГАОО. Ф. 6. ОП. 10. Д. 3275$)$. В 1824 г. за захват русских людей в плен ссылали в Иркутскую губернию (ГАОО. Ф. 6. Оп. 10. Д. 3236).

В 1831 г. за убийство стали также ссылать в Сибирь (ГАОО. Ф. 6. Оп. 10. Д. 3731/1).

В 1832 г. были вновь захвачены в плен рыбопромышленники (ГАОО. Ф. 6. Оп. 10. Д. 3836).

В 1834 г. в целях защиты рыбаков был установлен военный пост на берегу Каспийского моря (ГАОО. Ф. 6. Оп. 10. Д. 4128). Но и это не помогло. Рыбаки были вновь захвачены (ГАОО. Ф. 6. Оп. 10. Д. 4188). Для задержания разбойников в Степь был сразу же отправлен казачий отряд (ГАОО. Ф. 6. Оп. 10. Д. 4248).

Захваты русских рыбаков в море в 1835 и 1836 гг. продолжались (ГАОО. Ф. 6. Оп. 10. Д. 4388; ГАОО. Ф. 6. Оп. 1О. Д. 4529; ГАОО. Ф. 6. Оп. 10. Д. 4546). 


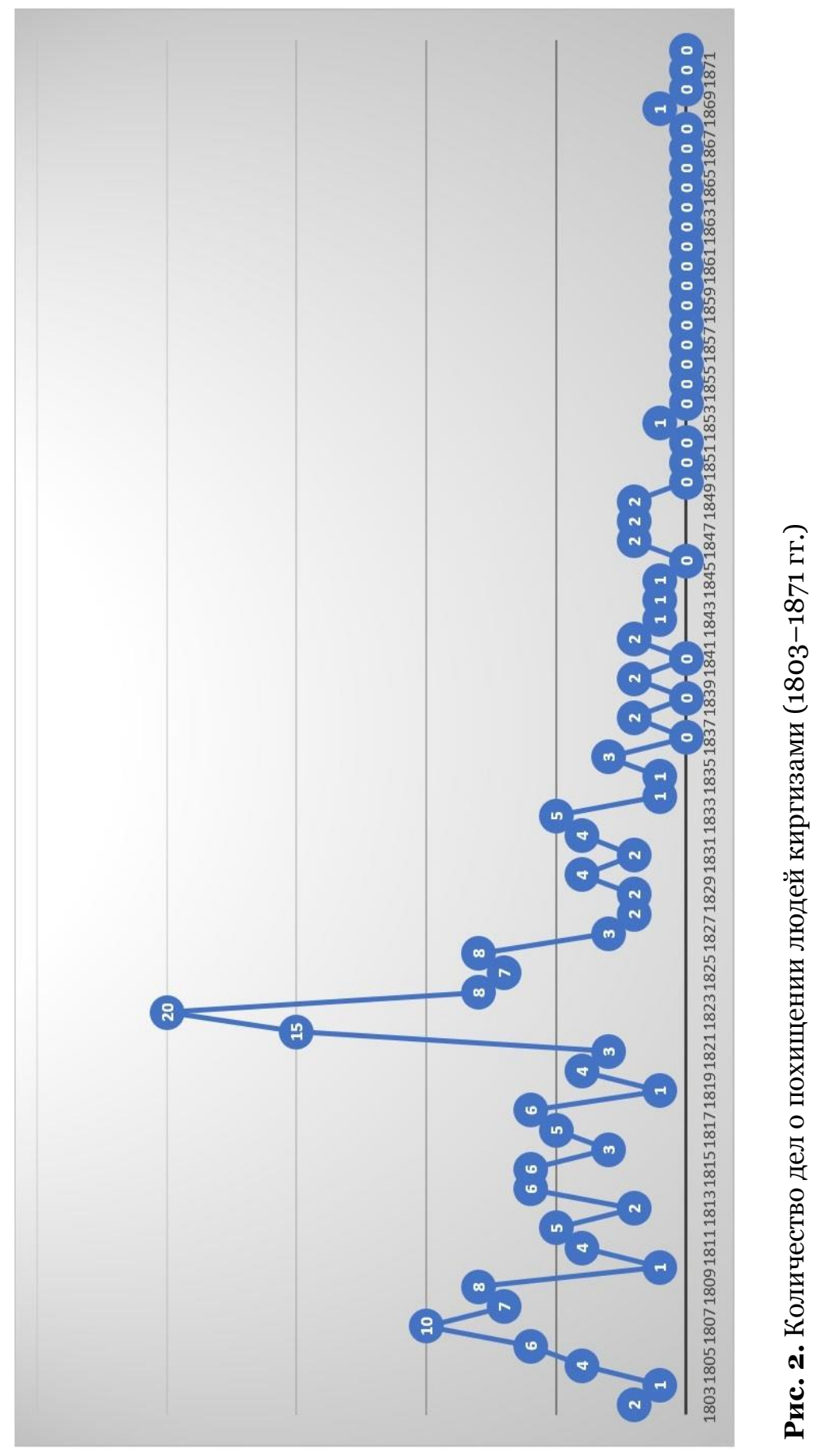

Для предотвращения морского разбоя на Оренбургской линии были задержаны хивинские купцы. Русская администрация требовала возвращения россиян (ГАОО. Ф. 6. Оп. 10. Д. 4537).

В 1836 г. с целью усмирить киргизов в Степь был отправлен экспедиционный отряд (ГАОО. Ф. 6. Оп. 10. Д. 4549), и с этого же времени киргизов, виновных в разбое, убийствах, захвате русских людей, начали предавать военному суду (ГАОО. Ф. 6. Оп. 10. Д. 4564).

В 1838 г. также отправлялись казачьи отряды для усмирения киргизов (ГАОО. Ф. 6. Оп. 10. Д. 4875г). В 1839 г. в Степь отправлялась казачья команда для поиска банд (ГАОО. Ф. 6. Оп. 10. Д. 4970).

В 1839 г. сразу 80 русских пленников были возвращены в Россию из Хивинского ханства (ГАОО. Ф. 6. Оп. 10. Д. 4993).

В 1847 г. на Каспийском море были вновь захвачены рыбаки (ГАОО. Ф. 6. Оп. 10. Д. 5882), в следующем году захват рыбаков повторялся (ГАОО. Ф. 6. Оп. 10. Д. 5941). Для пресечения налетов на рыбаков с 1848 г. начал применяться выход в море русских военных шхун (ГАОО. Ф. 6. ОП. 10. Д. 5960).

В 1850 г. из бухарского плена были освобождены русские пленные (ГАОО. Ф. 6. Оп. 10. Д. 6380). 


\section{Борьба с грабежами}

На Рисунках 3 и 4 мы представили количество дел о грабежах торговых караванов (18031879 гг.) и количество дел о других тяжких преступлениях, в том числе убийствах (1801-1877 гг.)

Первый случай документальной фиксации грабежа торгового каравана был зарегистрирован в документах Государственного архива Оренбургской области в 1803 г. (ГАОО. Ф. 6. Оп. 10. Д. 17), а первый случай грабежа рыбопромышленников в Каспийском море был зафиксирован 3 августа 1811 г. (ГАОО. Ф. 6. Оп. 10. Д. 834/15). В декабре 1814 г. был ограблен купец (ГАОО. Ф. 6. Оп. 10. Д.1148). В 1815 г. были ограблены сразу два торговых каравана: в июле и в сентябре (ГАОО. Ф. 6. Оп. 10. Д. 1299; ГАОО. Ф. 6. Оп. 10. Д. 1342). С целью защиты торговых караванов в Степи с 1815 г. русской администрацией стала применяться вооруженная охрана (ГАОО. Ф. 6. Оп. 10. Д. 1352) из представителей казахского населения. Под ограбления попадали и служащие почты. В 1817 г. за ограбление почты преступники наказывались плетью (ГАОО. Ф. 6. Оп. 10. Д. 1561). При отягчающих обстоятельствах их отправляли на каторгу (ГАОО. Ф. 6. Оп. 10. Д. 1642).

В мае 1817 г. был ограблен еще один торговый караван (ГАОО. Ф. 6. Оп. 10. Д. 1598). С этого времени за грабежи караванов преступников стали наказывать кнутом и отправлять на каторгу (ГАОО. Ф. 6. ОП. 10. Д. 1778).

Тем не менее нападения на караваны не прекращались. В июне 1818 г. нападение было совершено еще на один караван (ГАОО. Ф. 6. Оп. 1О. Д. 1877), а в 1819 г. - еще на два (ГАОО. Ф. 6. Оп. 10. Д. 1949; ГАОО. Ф. 6. ОП. 10. Д. 1999). Для освобождения хивинского каравана из плена 29 мая 1819 г. в Киргизскую степь был направлен казачий отряд (ГАОО. Ф. 6. Оп. 10. Д. 2044).

12 июня 1819 г. кочевники впервые ограбили целое русское рыболовецкое судно, до этого нападения совершались только на рыбацкие лодки (ГАОО. Ф. 6. Оп. 10. Д. 2065).

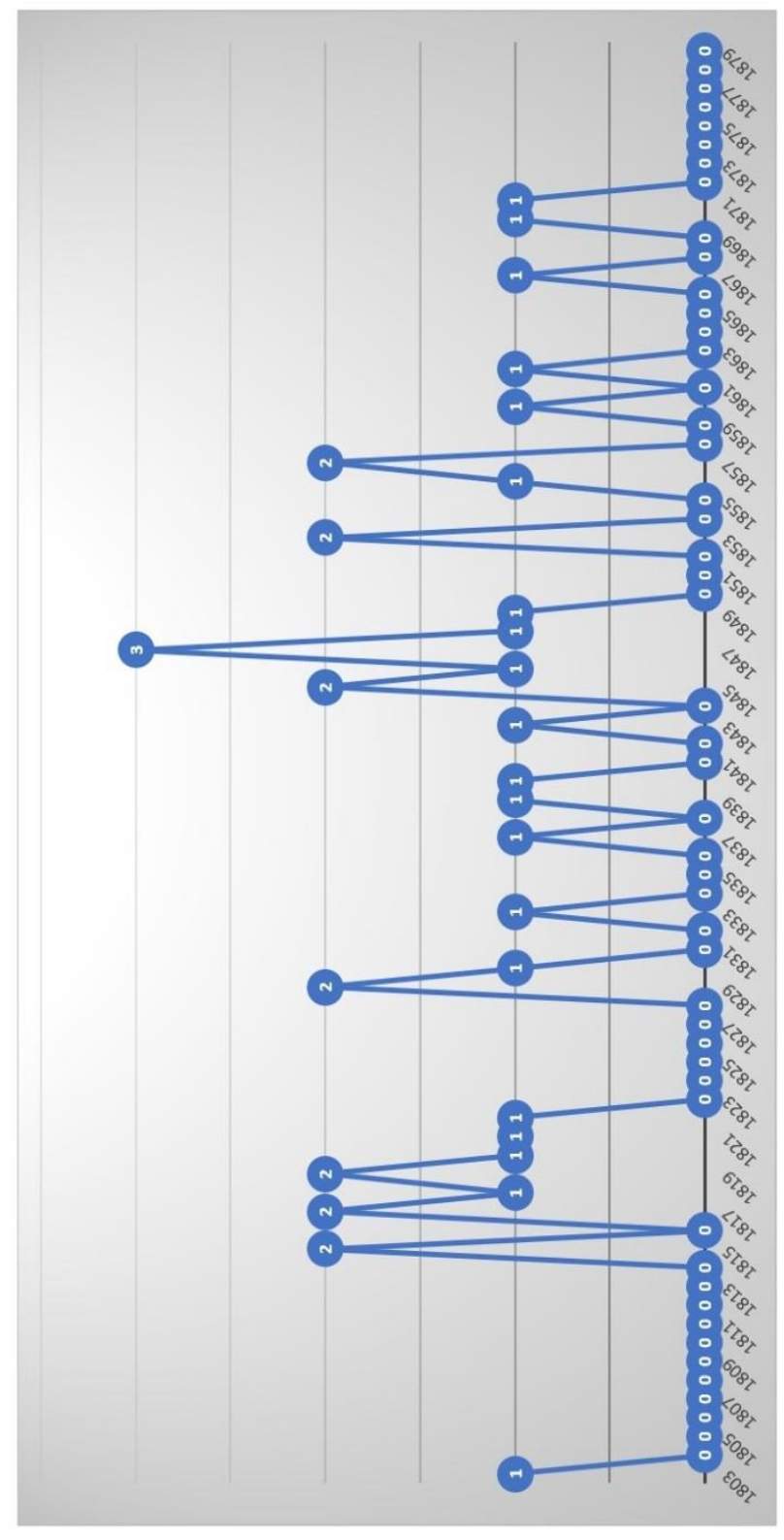




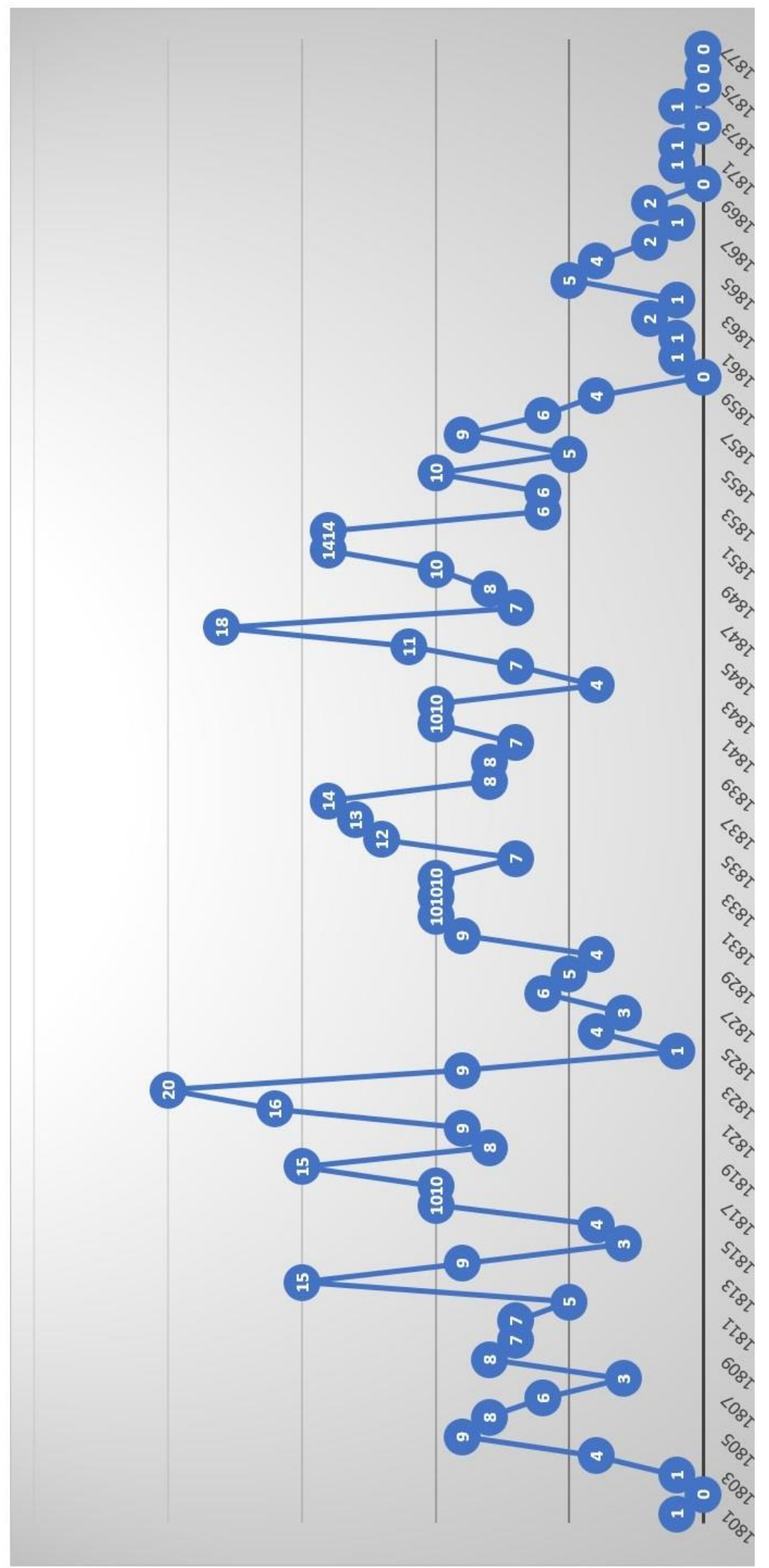

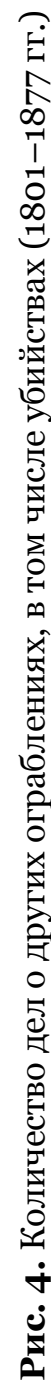

В 1829 г., в мае и декабре, были ограблены два каравана, один из которых бухарский (ГАОО. Ф. 6. Оп. 10. Д. 3550; ГАОО. Ф. 6. Оп. 10. Д. 3566). Важно пояснить, что между Бухарой и Хивой в 
рассматриваемое время было соперничество за право ведения торговли с русскими. При этом соперничающие ханства подстрекали кочевников на разграбление конкурентных караванов.

В 1833 г. русскими за ограбление каравана стала применяться мера возмещения ущерба (ГАОО. Ф. 6. Оп. 10. Д. 4106).

В 1837 г. ограбление торговых караванов повторилось (ГАОО. Ф. 6. Оп. 10. Д. 4642). Они были ограблены и в 1839 г., и в 1840 г. (ГАОО. Ф. 6. Оп. 10. Д. 5014; ГАОО. Ф. 6. Оп. 10. Д. 5089). Грабежи караванов продолжались и в 1843 г., и в 1845 г. (ГАОО. Ф. 6. Оп. 10. Д. 5377; ГАОО. Ф. 6. Оп. 10. Д. 5620).

К концу 1840-х гг., понимая, что за похищение рыбаков следует практически неотвратимая кара, киргизы начинают практиковать ограбления рыбаков. Такой случай был зафиксирован в 1847 г. (ГАОО. Ф. 6. ОП. 10. Д. 5818). В тот же год был вновь ограблен торговый караван (ГАОО. Ф. 6. ОП. 10. Д. 5866).

В 1849 г. были вновь ограблены киргизы-почтари (ГАОО. Ф. 6. Оп. 10. Д. 6220), в 1851 г. подобное преступление повторилось (ГАОО. Ф. 6. Оп. 10. Д. 6554).

В 1853 г. Был ограблен торговый караван (ГАОО. Ф. 6. Оп. 10. Д. 6844).

В 1854 г. почтари ограблены вновь (ГАОО. Ф. 6. Оп. 10. Д. 6997), а в 1856 и 1857 гг. ограблены еще 2 каравана (ГАОО. Ф. 6. Оп. 10. Д. 7246; ГАОО. Ф. 6. Оп. 10. Д. 7280).

В 1866 г. было зафиксировано ограбление на рыбном промысле (ГАОО. Ф. 6. Оп. 10. Д. 8о99), а в 1867 г. шайкой был ограблен торговый караван (ГАОО. Ф. 6. Оп. 10. Д. 8180).

Ограбление каравана произошло и в 1870-м г. (ГАОО. Ф. 6. Оп. 10. Д. 8309), аналогичное ограбление было зафиксировано и в 1871 г. (ГАОО. Ф. 6. Оп. 10. Д. 8330).

\section{Борьба с барымтой}

На Рисунке 5 представлена выборка дел о барымте в период 1803-1879 гг.

Согласно документам Государственного архива Оренбургской области, первые случаи барымты были зафиксированы еще в 1804 г., когда были похищены в двух кражах 700 и 1,5 тыс. лошадей (ГАОО. Ф. 6. ОП. 10. Д. 43; ГАОО. Ф. 6. Оп. 10. Д. 86). Уже в 1810-е гг. с целью предотвращения барымты (массового угона лошадей и другого крупного скота) русская администрация начала применять высылку преступников во внутренние регионы Российской империи (ГАОО. Ф. 6. Оп. 10. Д. 1072), как правило на Русский Север. Годные к военной службе преступники за барымту отправлялись на службу в Киевский гарнизон (ГАОО. Ф. 6. Оп. 10. Д. 1100). Иногда за этот вид преступления наказывали розгами (ГАОО. Ф. 6. Оп. 10. Д. 1350), а в случае отягчающих обстоятельств отправка на службу в Киевский гарнизон и розги применялись в качестве наказания одновременно (ГАОО. Ф. 6. ОП. 10. Д. 1479).

В ноябре 1820 г. с целью прекратить похищение лошадей русская администрация рассматривала идею увеличения количества казачьих пикетов на границе (ГАОО. Ф. 6. Оп. 10. Д. 2360).

В 1833 г. за барамту наказывали палками (ГАОО. Ф. 6. Оп. 10. Д. 4088).

В 1836 г. был осуществлен один из самых громких угонов лошадей. За один раз было угнано 4226 лошадей (ГАОО. Ф. 6. Оп. 10. Д. 4509).

В 1838 г. был зафиксирован случай, когда за похищение лошадей сослали преступника в Лифляндский инженерный округ (ГАОО. Ф. 6. Оп. 10. Д. 4786).

В 1845 г. киргизы угнали табун из 500 лошадей (ГАОО. Ф. 6. Оп. 10. Д. 5649), а в 1846 г. 1,8 тыс. лошадей (ГАОО. Ф. 6. ОП. 10. Д. 5744). В 1847 г. было угнано 950 лошадей (ГАОО. Ф. 6. ОП. 10. Д. 5816).

В 1848 г. на барымту отреагировал даже Правительсвующий сенат Российской империи, который опубликовал указ от 12.02.1848 г. № 8250 о борьбе с конокрадством (ГАОО. Ф. 6. Оп. 10. Д. 5996).

В 1849 г. было несколько крупных угонов: 300 (ГАОО. Ф. 6. Оп. 10. Д. 5944) и 400 лошадей (ГАОО.Ф. 6. ОП. 10. Д. 6224).

В 1864 г. в барымте стали участвовать только шайки известных лиц (ГАОО. Ф. 6. Оп. 10. Д. 7927; ГАОО.Ф. 6. ОП. 10. Д. 8060).

\section{Эволюция мировоззрения}

На эволюцию мировоззрения серьезное воздействие оказывали как репрессивные, так и поощрительные меры. Рассмотрим эти примеры в хронологическом порядке.

Так, за побег из-под стражи в начале 1820-х гг. провинившихся наказывали плетью (ГАОО. Ф. 6. Оп. 10. Д. 2565), за ложный донос - палками (ГАОО. Ф. 6. Оп. 10. Д. 2566). Нужно понимать, что в это время ситуация даже во Внутренней орде была неспокойной. В 1822 г. султан Средней орды просил у оренбургского генерал-губернатора выделить воинский отряд для защиты его самого от набегов (ГАОО.Ф. 6. Оп. 10. Д. 2628). 


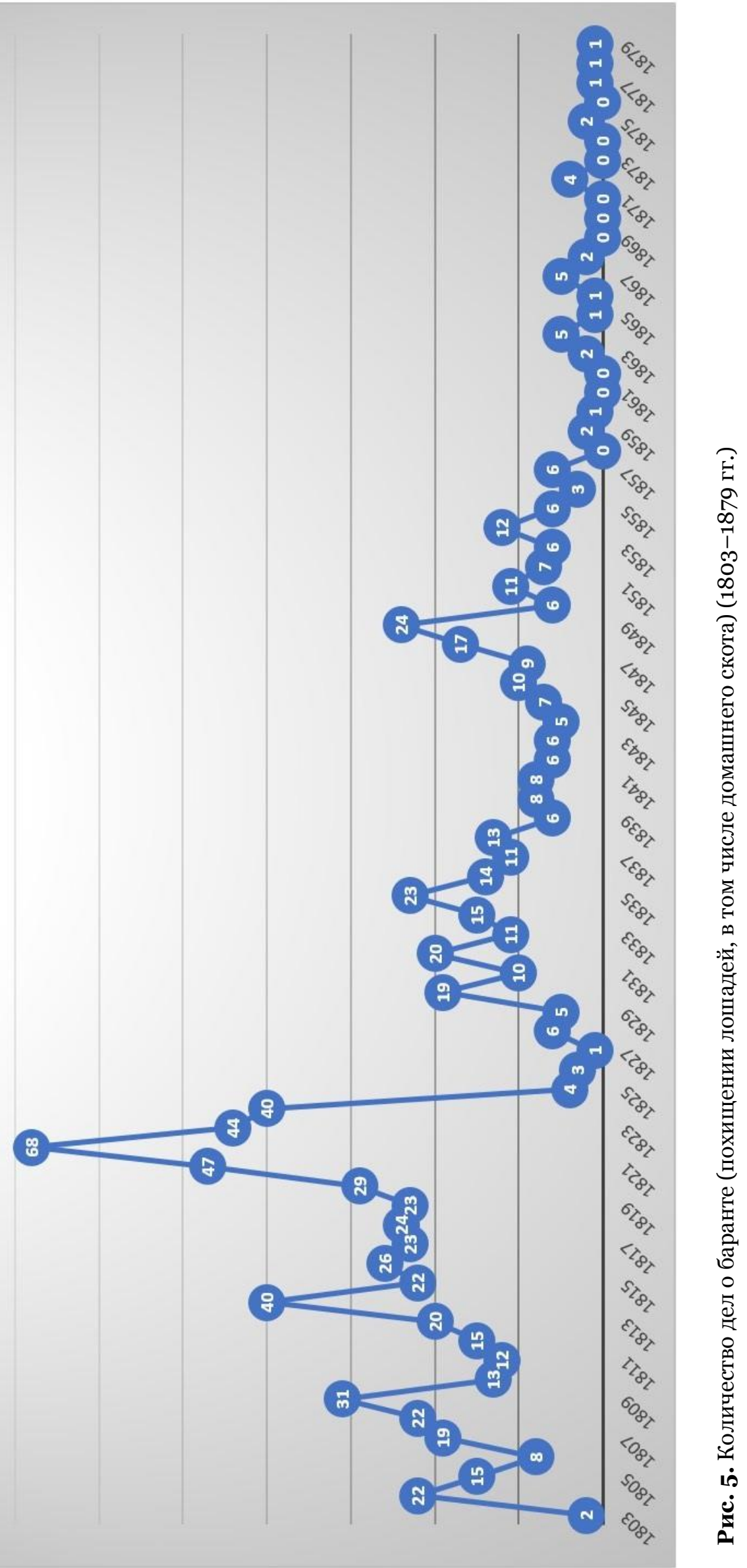


Уже в 1820 г. во Внутренней орде делались попытки начать обучение киргизских детей грамоте (ГАОО. Ф. 6. ОП. 10. Д. 2254), а в 1824 г. во Внутренней орде правительством была осуществлена покупка киргизских и калмыцких девочек для переселения в Западную Сибирь, где существовала большая нехватка женского населения (ГАОО. Ф. 6. Оп. 10. Д. 3234).

Сильно наказывалось бродяжничество. В 1830-м г. за бродяжничество выселяли в Иркутскую губернию (ГАОО. Ф. 6. Оп. 10. Д. 3688). Необходимо пояснить, что бродяги часто сообщали информацию об увиденном преступникам и, по сути, наводили их на объект грабежа.

26 марта 1831 г. был зафиксирован первый случай изнасилования (ГАОО. Ф. 6. Оп. 10. Д. 3747). Нужно понимать, что обычно о таких фактах информация не сообщалась, так как была связана с бесчестием женщины. Тем не менее несколько таких случаев было официально зафиксировано.

В 1833 г. начались работы по перенесению пограничной линии дальше в Киргизскую степь (ГАОО. Ф. 6. Оп. 10. Д. 4290), это должно было резко сократить количество набегов кочевников на русскую территорию.

В 1834 г. жители Григорьевского форпоста получили разрешение развести заповедный лес, а именно ценные породы (ГАОО. Ф. 6. ОП. 10. Д. 4157).

В 1835 г. русская администрация занималась устройством по домам киргизских детей, которых неимущие родители оставили на меновых дворах (ГАОО. Ф. 6. Оп. 10. Д. 4276). В том же 1835 г. русским правительством были выделены средства на устройство непрерывного рва и вала по новой Зауральской линии с целью обороны русской границы от набегов кочевников (ГАОО. Ф. 6. Оп. 10. Д. 4570).

С 1837 г. стала применяться ссылка и в Финляндию (ГАОО. Ф. 6. Оп. 10. Д. 4663/1).

В 1840 г. ввиду суровой зимы и падежа скота русское правительство выделило 10 тыс. руб. на покупку хлеба для нуждающихся киргизов (ГАОО. Ф. 6. Оп. 10. Д. 5134а).

В 1844 г. стала засчитываться ответственность хозяев за проступки нанятых ими киргизов (ГАОО. Ф. 6. Оп. 10. Д. 5565). В том же году была открыта фельдшерская школа для киргизских детей (ГАОО. Ф. 6. Оп. 10. Д. 5569е), а 1846 г. создана еще одна школа для них (ГАОО. Ф. 6. Оп. 10. Д. 5633).

В 1847 г. был объявлен запрет на вход в Оренбург киргизским нищим, так как было установлено, что они содействуют киргизским ворам (ГАОО. Ф. 6. Оп. 10. Д. 5895м).

В 1848 г. неимущие киргизы были освобождены от кибиточного сбора, то есть от налогов (ГАОО. Ф. 6. Оп. 10. Д. 5919). В том же году в Оренбурге была создана школа для киргизских детей (ГАОО. Ф. 6. ОП. 10. Д. 5924 а).

В 1849 г. в ставке правителя Восточной орды была открыта киргизская школа (ГАОО. Ф. 6. Оп. 10. Д. 6170).

В 1850 г. при школе для киргизских детей была создана больница (ГАОО. Ф. 6. Оп. 10. Д. 6403). В этом же году принимались меры по обеспечению киргизов медицинскими работниками (ГАОО. Ф. 6. Оп. 10. Д. 6419). Д. 6925).

С 1854 г. началось обеспечение киргизских детей продовольствием в школе (ГАОО. Ф. 6. Оп. 10.

В 1856 г. за разбой оренбургские киргизы стали вновь определяться в солдаты (ГАОО. Ф. 6. Оп. 10. Д. 7213). В этом же году киргизов, бежавших из ссылки, стали предавать военному суду (ГАОО. Ф. 6. ОП. 10. Д. 7255).

В 1858 г. стали открываться школы для киргизских детей и в военных укреплениях (ГАОО. Ф. 6. Оп. 10. Д. 7473). В этом же году после отбытия каторги в Сибири на родину стали возвращаться киргизы (ГАОО. Ф. 6. Оп. 10. Д. 7485).

С 1859 г. применялось выселение киргизов с целью предотвращения воровства (ГАОО. Ф. 6. Оп. 10. Д. 7515), при этом в том же году оказывалась помощь неимущим киргизам из-за морозов (ГАОО. Ф. 6. ОП. 10. Д. 7515). В этом же году киргизов-уголовников, то есть уже наказанных ранее за уголовные преступления, стали отдавать в солдаты (ГАОО. Ф. 6. Оп. 10. Д. 7531). 1859 г. был богат на события. В это же время начали создаваться киргизские караульные команды (ГАОО. Ф. 6. ОП. 10. Д. 7565).

В 1861 г. в Киргизскую орду были направлены казачки для обучения киргизских женщин пуховязанию (ГАОО. Ф. 6. Оп. 10. Д. 7691).

В 1862 г. была создана единая система сбора податей (ГАОО. Ф. 6. Оп. 10. Д. 7741). В том же году неимущие больные киргизы получили право бесплатно обращаться в больницы Оренбургского казачьего войска (ГАОО. Ф. 6. Оп. 10. Д. 7765), в это же время в киргизской школе в ставке хана Внутренней орды была открыта первая библиотека (ГАОО. Ф. 6. Оп. 10. Д. 7807).

В 1863 г. для предотвращения голода в киргизских аулах Восточной части орды создаются частные хлебные запасы (ГАОО. Ф. 6. Оп. 10. Д. 7926).

В 1864 г. выпускники киргизских школ были определены на службу (ГАОО. Ф. 6. Оп. 10. Д. 7909). О степени принципиальных изменений в киргизском обществе говорит то, что в том же году киргизы-арестанты попросили книг и учителя (ГАОО. Ф. 6. Оп. 10. Д. 7957).

В 1865 г. в ставке хана Внутренней орды была создана больница (ГАОО. Ф. 6. Оп. 10. Д. 8004). В том же году осуществлялась раздача хлеба неимущим киргизам (ГАОО. Ф. 6. Оп. 10. Д. 8012).

$$
-1747-
$$


В 1869 г. в Орде создаются хлебные магазины (ГАОО. Ф. 6. Оп. 10. Д. 8159). Также в этом году запрещается въезд в Степь иностранцам и кавказским горцам (ГАОО. Ф. 6. Оп. 10. Д. 8265) - таким образом была запрещена религиозная пропаганда.

В 1872 г. были созданы уездные архивы (ГАОО. Ф. 6. Оп. 10. Д. 83883).

В 1873 г. у киргизов были введены метрические книги, что улучшало качество сбора информации о населении (ГАОО. Ф. 6. Оп. 10. Д. 8399), в том же году была взята Хива - один из оплотов работорговли в Азии (ГАОО. Ф. 6. Оп. 10. Д. 8406).

Этот краткий обзор наглядно демонстрирует, что вопросы диалога между русскими и киргизами не зависели сугубо от военных мероприятий Российской империи. Стремясь прекратить асоциальное поведение киргизов, Российская империя, наряду с военными, использовала целый арсенал мер, направленных на привлечение на русскую сторону как собственных киргизов (Внутренняя орда), так и киргизов Степи.

\section{5. Заключение}

Завершая, мы хотели бы обратить внимание на то, что в первой половине ХIX века Российская империя в Центральной Азии столкнулась с целым спектром тяжких уголовных преступлений, а именно с похищением людей и работорговлей, убийствами, ограблением торговых караванов и рыболовецких судов, набегами кочевников и барымтой (похищением лошадей и скота). Только в Государственном архиве Оренбургской области этим вопросам было посвящено около 2 тыс. архивных дел. В противоправных деяниях принимали участие, особенно на начальном этапе, не только кочевники Киргизской степи, но и киргизы, находящиеся в составе России (Внутренняя орда).

Начиная с 1820 г., Россия вела неустанную работу по распространению в Степи грамотности, оказанию медицинской и гуманитарной помощи, привлечению местного населения на службу (сначала почтарями, потом в охрану султанов и караванов, а далее - вплоть до поступления на государственную службу после окончания русских учебных заведений). Благодаря этому, Степь начала меняться, но этот процесс был долгим и сложным, однако в целом к 1870-м гг. количество уголовных преступлений в регионе было сведено к минимуму, и Центральная Азия смогла перенять многие инициативы, предложенные российской администрацией.

\section{6. Благодарности}

Публикация выполнена при поддержке Программы стратегического академического лидерства РУДН. / This paper has been supported by the RUDN University Strategic Academic Leadership Program.

\section{Литература}

Вдовин, Сыздыкова, 2021 - Вдовин С.С., Сыздыкова Ж.С. Этнический состав и территориальное устройство Хивинского ханства XVIII-XIX вв. // Bопросы национальнъх и Федеративных отношений. 2021. № 7(76). С. 1996-2004.

Зварцев, 2021 - Зварцев И.А. Окончательное завоевание Туркестана (Средней Азии) Российской империей // Вестник науки. 2021. № 8(41). С. 32-39.

Почекаев, 2020 - Почекаев Р.Ю. Использование российских войск в среднеазиатских протекторатах Российской империи // Военно-исторический журнал. 2020. № 3. С. 34-39.

Почекаев, 2015 - Почекаев Р.Ю. Особенности правового регулирования статуса российских торговцев в Бухарском эмирате и Хивинском ханстве во второй половине XIX - начале XX вв. // Восток. Афро-Азиатские общества: история и современность. 2015. № 6. С. 38-44.

Ганиев, 2013 - Ганиев Р.Т. Хивинская проблема Российской империи в первой половине XIX в.: амбиции и реальность // Известия Уральского федерального университета. Серия 2 «Гуманитарные науки». 2013. № 2(114). С. 107-123.

Годовова, 2019 - Годовова E.B. Присоединение Средней Азии к России: особенности военнопоходной повседневности казаков в Хивинском походе 1873 г. // Электронный научнообразовательный журнал «История». 2019. № 8(82). С. 6.

Любичанковский, 2017 - Любичанковский С.B. Кризисные явления в развитии среднеазиатского направления внешней торговли России на оренбургском направлении в первой четверти XIX века // Самарский научный вестник. 2017. № 2(19). С. 132-135.

Мухамедина, 2016 - Мухамедина Ш. Водворение русской гражданственности в Центральной Азии (1865-1886 гг.) // Вестник Московского государственного областного университета. Серия «История и политические науки». 2016. № 1. С. 106-122.

Ermachkov, 2021 - Ermachkov I.A., Vidishcheva E.V., Mineeva E.K., Balanyuk L.L. The Features of the Capture of Russian People by Asian Nomadic Tribes (the first half of the XIX century) // Bylye Gody. 2021. 16(3): 1171-1180.

Izbassarova, 2020 - Izbassarova G.B. Legitimization of Power in the Kazakh Steppe in the XIX century. Search for the Cartridge: Khiva Khanate or Russian Empire? (by the Example of the Fate of Sultan Kaipgali Ishimov) // Bylye Gody. 2020. 58(4): 2385-2395. 
Poullada, 2018 - Poullada S.P. Russian-Turkmen encounters. The Caspian frontier before the Great Game. London, 2018.

Zinkovskii et al., 2021 - Zinkovskii S.B., Malakhova V.Yu., Denisov I.S., Makarov Yu.N. Circassian and Central Asian Slavery: The General and Special (on the Example of Cases of the Return of Russian Prisoners) // Bylye Gody. 2021. 16(2): 689-698.

Tarasov, 2021 - Tarasov M.G. Cossacks in the Khiva Crusade of 1839-1840 // Bylye Gody. 2021. 16(3): 1181-1190.

\section{References}

Ermachkov, 2021 - Ermachkov, I.A., Vidishcheva, E.V., Mineeva, E.K., Balanyuk, L.L. (2021). The Features of the Capture of Russian People by Asian Nomadic Tribes (the first half of the XIX century). Bylye Gody. 16(3): 1171-1180.

Ganiev, 2013 - Ganiev, R.T. (2013). Khivinskaya problema Rossiiskoi imperii v pervoi polovine XIX v.: ambitsii i real'nost' [The Khiva problem of the Russian Empire in the first half of the 19th century: ambitions and reality]. Izvestiya Ural'skogo federal'nogo universiteta. Seriya 2: Gumanitarnye nauki. 2(114): 107-123. [in Russian]

Godovova, 2019 - Godovova, E.V. (2019). Prisoedinenie Srednei Azii k Rossii: osobennosti voennopokhodnoi povsednevnosti kazakov v Khivinskom pokhode $1873 \mathrm{~g}$. [The annexation of Central Asia to Russia: the peculiarities of the military marching everyday life of the Cossacks in the Khiva campaign of 1873]. Elektronnyi nauchno-obrazovatel'nyi zhurnal «Istoriya». 8(82): 6. [in Russian]

Izbassarova, 2020 - Izbassarova, G.B. (2020). Legitimization of Power in the Kazakh Steppe in the XIX century. Search for the Cartridge: Khiva Khanate or Russian Empire? (by the Example of the Fate of Sultan Kaipgali Ishimov). Bylye Gody. 58(4): 2385-2395.

Lyubichankovskii, 2017 - Lyubichankovskii, S.V. (2017). Krizisnye yavleniya v razvitii sredneaziatskogo napravleniya vneshnei torgovli Rossii na orenburgskom napravlenii $\mathrm{v}$ pervoi chetverti XIX veka [Crisis phenomena in the development of the Central Asian direction of Russia's foreign trade in the Orenburg direction in the first quarter of the XIX century]. Samarskii nauchnyi vestnik. 2(19): 132-135. [in Russian]

Mukhamedina, 2016 - Mukhamedina, Sh. (2016). Vodvorenie russkoi grazhdanstvennosti v Tsentral'noi Azii (1865-1886 gg.) [The establishment of Russian Citizenship in Central Asia (1865-1886)]. Vestnik Moskovskogo gosudarstvennogo oblastnogo universiteta. Seriya: Istoriya i politicheskie nauki. 1: 106-122. [in Russian]

Pochekaev, 2015 - Pochekaev, R.Yu. (2015). Osobennosti pravovogo regulirovaniya statusa rossiiskikh torgovtsev $\mathrm{v}$ Bukharskom emirate i Khivinskom khanstve vo vtoroi polovine XIX - nachale XX vv. [The features of the legal regulation of the status of Russian merchants in the Bukhara Emirate and the Khiva Khanate in the second half of the 19th - early 2oth centuries]. Vostok. Afro-Aziatskie obshchestva: istoriya $i$ sovremennost'. 6: 38-44. [in Russian]

Pochekaev, 2020 - Pochekaev, R.Yu. (2020). Ispol'zovanie rossiiskikh voisk v sredneaziatskikh protektoratakh Rossiiskoi imperii [The use of Russian troops in the Central Asian protectorates of the Russian Empire]. Voenno-istoricheskii zhurnal. 3: 34-39. [in Russian]

Poullada, 2018 - Poullada, S.P. (2018). Russian-Turkmen encounters. The Caspian frontier before the Great Game. London.

Vdovin, Syzdykova, 2021 - Vdovin, S.S., Syzdykova, Zh.S. (2021). Etnicheskii sostav i territorial'noe ustroistvo Khivinskogo khanstva XVIII-XIX vv. [The ethnic composition and territorial structure of the Khiva Khanate of the 18th - 19th centuries.]. Voprosy natsional'nykh i federativnykh otnoshenii. 7(76): 1996-2004. [in Russian]

Zinkovskii et al., 2021 - Zinkovskii, S.B., Malakhova, V.Yu., Denisov, I.S., Makarov, Yu.N. (2021). Circassian and Central Asian Slavery: The General and Special (on the Example of Cases of the Return of Russian Prisoners). Bylye Gody. 16(2): 689-698.

Zvartsev, 2021 - Zvartsev, I.A. (2021). Okonchatel'noe zavoevanie Turkestana (Srednei Azii) Rossiiskoi imperiei [The final conquest of Turkestan (Central Asia) by the Russian Empire]. Vestnik nauki. 8(41): 32-39. [in Russian]

Tarasov, 2021 - Tarasov, M.G. (2021). Cossacks in the Khiva Crusade of 1839-1840. Bylye Gody. 16(3): 1181-1190. 


\title{
Цивилизационная миссия Российской империи в Центральной Азии в XIX веке (на материалах Государственного архива Оренбургской области)
}

\author{
Валерий Леонидович Музыкант а, *, Галина Николаевна Трофимова а, \\ Валерий Дзантемирович Таказов ${ }^{\text {a }, ~ А л м а с ~ К а л и м о л д а е в ~}{ }^{\mathrm{b}}$ \\ а Российский университет дружбы народов, Москва, Российская Федерация \\ b Казахский национальный университет имени Аль-Фараби, Алматы, Казахстан
}

Аннотация. В работе на основе архивных источников рассматривается цивилизационная миссия Российской империи в Центральной Азии в XIX веке. Уделено внимание основным видам преступлений, таким как похищение людей, убийство, ограбление торговых караванов, морской разбой, барымта, а также системе наказаний за эти преступления.

В качестве материалов была использована опись № 10 (1-4 части) фонда № 6 Государственного архива Оренбургской области (Оренбург, Российская Федерация), в которой представлены дела пограничного отделения канцелярии оренбургского генерал-губернатора.

В заключении авторы отмечают, что в первой половине XIX века Российская империя в Центральной Азии столкнулась с целым спектром тяжких уголовных преступлений, а именно с похищением людей и работорговлей, убийствами, ограблением торговых караванов и рыболовецких судов, набегами кочевников и барымтой (похищением лошадей и скота). Только в Государственном архиве Оренбургской области этим вопросам было посвящено около 2 тыс. архивных дел. В противоправных деяниях принимали участие, особенно на начальном этапе, не только кочевники Киргизской степи, но и киргизы, находящиеся в составе России (Внутренняя орда).

Начиная с 1820 г., Россия вела неустанную работу по распространению в Степи грамотности, оказанию медицинской и гуманитарной помощи, привлечению местного населения на службу (сначала почтарями, потом в охрану султанов и караванов, а далее - вплоть до поступления на государственную службу после окончания русских учебных заведений). Благодаря этому, Степь начала меняться, но этот процесс был долгим и сложным, однако в целом к 1870-м гг. количество уголовных преступлений в регионе было сведено к минимуму, и Центральная Азия смогла перенять многие инициативы, предложенные российской администрацией.

Ключевые слова: Центральная Азия, Хива, Бухара, Внутренняя орда, кочевники, Киргизская степь, Российская империя, Персия.

\footnotetext{
* Корреспондирующий автор

Адреса электронной почты: muzykant_vl@pfur.ru (В.Л. Музыкант) 